Sains Malaysiana 49(10)(2020): 2539-2545

http://dx.doi.org/10.17576/jsm-2020-4910-19

\title{
Temperature Performance of a Portable Solar Greenhouse Dryer with Various Collector Design
}

(Prestasi Suhu Pengering Rumah Hijau Suria Mudah Alih dengan Pelbagai Reka Bentuk Pengumpulan)

\author{
Nurul Aiman Mhd Safri, Zalita Zainuddin*, Mohd Syahriman Mohd AZmi, Ahmad Fudholi, Idris \\ ZULKIFLE \& MOHD HAFIDZ RUSLAN
}

\begin{abstract}
The two main components of a solar greenhouse drying system are the solar collector and drying chamber. Solar greenhouse utilized thermal energy to increase the temperature in the drying chamber at an optimum rate for drying purposes with the use of solar collectors. In this study the performance of a self-built portable solar greenhouse dryer using different types of solar collectors were evaluated, which are flat plate with insulator, V-groove with insulator, flat plate and V-groove with insulator and flat plate and V-groove without insulator. The experiment was conducted indoor, in the solar simulator laboratory using halogen lamps. Two parameters were varied, which are the mass flow rates at $0.011,0.021,0.030$, and $0.041 \mathrm{~kg} / \mathrm{s}$, and the light intensities at $625,708,860$, and $988 \mathrm{~W} / \mathrm{m}^{2}$. The collector outlet temperature for every solar collector design was compared to each other. The results showed that for all types of collector, the combination of the maximum solar radiation intensity of $988 \mathrm{~W} / \mathrm{m}^{2}$ and the lowest mass flow rate of $0.011 \mathrm{~kg} / \mathrm{s}$ produced the highest average maximum collector outlet temperature. Whereas, the highest efficiency is at the highest mass flow rate of $0.041 \mathrm{~kg} / \mathrm{s}$ and the minimum solar radiation intensity of $625 \mathrm{~W} / \mathrm{m}^{2}$. In this study it was found that the solar collector that has the best performance of heat transfer is the combination of flat-plate and V-groove collector with an insulator under the V-groove while the best collector design for drying purpose is the combination of flat-plate and V-groove collector without insulator.
\end{abstract}

Keywords: Efficiency; performance; solar greenhouse dryer; V-groove collector

ABSTRAK

Dua komponen utama bagi sistem pengering rumah hijau suria adalah pengumpul suria dan kebuk pengeringan. Rumah hijau suria menggunakan tenaga terma untuk meningkatkan suhu di dalam kebuk pengeringan pada kadar yang optimum untuk tujuan pengeringan dengan penggunaan pengumpul suria. Dalam kajian ini, prestasi pengering rumah hijau suria mudah alih swabina menggunakan pengumpul suria berbeza jenis telah dinilai iaitu, plat-datar dengan penebat, lekuk-V dengan penebat, gabungan plat-datar dan lekuk-V dengan penebat dan gabungan plat-datar dan lekuk-V tanpa penebat. Uji kaji telah dijalankan di dalam makmal simulator suria yang menggunakan lampu halogen. Dua parameter telah diubah iaitu, kadar aliran jisim pada 0.011, 0.021, 0.030 dan $0.041 \mathrm{~kg} / \mathrm{s}$ dan keamatan cahaya pada 625, 708, 860 dan $988 \mathrm{~W} / \mathrm{m}^{2}$. Suhu keluar pengumpul untuk setiap reka bentuk pengumpul suria telah dibandingkan antara satu sama lain. Keputusan kajian menunjukkan bahawa gabungan keamatan sinar suria maksimum bagi 988 $W / \mathrm{m}^{2}$ dan kadar aliran jisim paling rendah bagi $0.011 \mathrm{~kg} / \mathrm{s}$ telah mencapai suhu keluar pengumpul dengan purata maksimum yang paling tinggi untuk semua jenis pengumpul. Manakala kecekapan tertinggi adalah pada kadar aliran jisim tertinggi iaitu pada $0.041 \mathrm{~kg} / \mathrm{s}$ dan keamatan sinar suria minimum pada $625 \mathrm{~W} / \mathrm{m}^{2}$. Kajian ini juga mendapati bahawa pengumpul suria dengan prestasi pemindahan haba terbaik adalah gabungan plat-datar dan lekuk-V dengan penebat di bawah lekuk-V manakala reka bentuk pengumpul suria terbaik bagi tujuan pengeringan adalah gabungan plat-datar dan lekuk-V tanpa penebat.

Kata kunci: Kecekapan; pengering rumah hijau suria; pengumpul berlekuk-V; prestasi

\section{INTRODUCTION}

Solar energy is a potential energy resource in Malaysia due to a substantial amount of solar radiation received throughout the year (Sopian \& Othman 1992). The application of solar energy for the drying process by exposing the product under solar radiation could preserve the quality of food, crops or commodities and this is the traditional solar drying method. Drying is a process of moisture removal due to simultaneous heat and mass transfer (El-sebaii \& Shalaby 2012). The percentage of 
dryness depends on the moisture content in the agricultural products either on a wet basis or a dry basis (Prakash \& Kumar 2014). Various agricultural and marine products need drying process for gaining a quality final product (Othman et al. 2012). Open sun drying is widely used for drying commodities however, its large drawbacks such as fungal and insect infestations and contamination of foreign materials leads to solar dryer as an alternative for applications in solar energy systems (Fudholi et al. 2013). Solar drying system is an environmentally safe and renewable system appliance that utilized solar energy as a source of heat energy to be transmitted through the crops then exhausts the humidity from its surface during drying process while preserving its' quality. The solar drying systems encompassed of indirect, direct, and mixed dryer. Solar dryers such as the cabinet, solar tunnel, tent, and greenhouse dryer could be built in a certain system that depends on its' exposure towards solar radiation.

A greenhouse is a structure covered with transparent materials that utilize solar radiant energy and provide optimum growing conditions for plants (Hassanien et al. 2016). Due to the greenhouse effect working mechanism, crops cultivation is usually settled in a greenhouse and has been practised in high latitude countries. However, in tropical and subtropical countries, usually greenhouses were developed and utilized for drying purpose. The greenhouse structure is also being used for the purpose of low-temperature drying with the help of solar radiation from the last two and a half decades (Prakash et al. 2016). Greenhouse dryers have also been developed under passive and active modes.

Solar radiation can be transformed to heat energy and then supplied to thermal storage when in need of the utilization of solar collectors (Evangelisti et al. 2019). The solar collectors are a major technology in solar energy system due to its capability of absorbing thermal heat energy (Zulkifle et al. 2018). Solar collectors can be constructed as thermal storage for zone heating, timber seasoning, solar cookers, hot water utilization and drying of agricultural and industrial commodities (Evangelisti et al. 2019; Fudholi \& Sopian 2019). The solar collector is functioned with thermal convection mode such as the passive and active mode in drying application. Solar greenhouse dryers are often equipped with solar collectors, drying chamber and thermal storage as a heat supply during rain or at night.

Thermal performance of the absorber of the air solar collector for an indirect solar dryer under the natural convection of pear drying was studied by Essalhi et al. (2017). The results of the study showed that the maximum temperature of the collector outlet achieved $57^{\circ} \mathrm{C}$, thus, showing that the design of the absorber provided good air ventilation. Shamekhi-Amiri et al. (2018) investigated the performance of the drying chamber which used heated air entering from a packed bed air heater.
The experiment was carried out by forced convection of an indirect solar dryer using a medicinal plant like lemon balm leaves. The result showed that by increasing the flow rate from 0.006125 to $0.01734 \mathrm{~m}^{3} / \mathrm{s}$, the collector thermal efficiency was enhanced approximately by $20 \%$. An adverse effect on the collector thermal efficiency occurred while increasing the flow rate any further to $0.034378 \mathrm{~m}^{3} / \mathrm{s}$. An experimental work of north wall insulated greenhouse dryer (NWIGHD) with the solar collector inside was introduced with novelty (Chauhan \& Kumar 2016). The NWIGHD with solar collector gave higher temperature of $65.2{ }^{\circ} \mathrm{C}$ to the inside room of the greenhouse and $4.4 \%$ lower inside room relative humidity which coped the most suitable characteristics of drying crops.

This study aimed to evaluate the performance of solar collectors with four different arrangements of back insulation, flat plate and V-groove at different mass flow rate and solar radiation. The efficiency of each solar collector was determined and the best collector design for drying application will be determined.

\section{MATERIALS AND METHODS}

A portable greenhouse dryer as shown in Figure 1 was developed and tested at the Solar Energy Laboratory in the Department of Applied Physics, Universiti Kebangsaan Malaysia, Bangi. The $126.0 \mathrm{~cm} \times 63.5 \mathrm{~cm} \times 118.8 \mathrm{~cm}$ dryer consists of a solar collector compartment (12.8 $\mathrm{cm}$ height) and drying chamber (78.0 cm height) with a portable bearing floor. Tempered glass of $6 \mathrm{~mm}$ thickness is put on top of the solar collector compartment to allow radiation penetration and provide insulation from heat loss of the collector. Acrylic glass of $4 \mathrm{~mm}$ thickness has been wall mounted to black painted iron frame forming compartments for the solar dryer. The acrylic glass can retain heat inside the dryer due to its' properties as a heat insulator. Besides having a good UV stability, it is also cost effective, light weight and shatter-resistant. The solar collector is connected to the drying chamber by a rubber hose of $9.8 \mathrm{~cm}$ in diameter. Type-K thermocouples with reading accuracy of $\pm 0.1^{\circ} \mathrm{C}$ were used to measure the inlet and outlet temperature as well as the temperature in the chamber. The temperatures were recorded with a DL2e data logger at every one minute. The Eppley black-andwhite pyranometer (Eppley Laboratory, Inc., USA) was used to measure the beam and diffused radiation during exposure to solar radiation. Pro'sKit anemometer model MT-4015 (Prokits, Malaysia) with accuracy of $\pm(2 \%+$ $0.5 \mathrm{~m} / \mathrm{s}$ ) was used to measure the speed of the fan at the solar collector duct.

The solar greenhouse dryer has been fitted with four types of solar collector as depicted in Figure 2, which are (a) flat-plate with insulator, (b) V-groove with insulator, (c) flat-plate and V-groove with insulator and (d) flatplate and V-groove without insulator. The V-groove and 
flat-plate are made using aluminium sheet. The V-groove has an angle of $57^{\circ}$ and was mounted on a $122.0 \mathrm{~cm} \times$ $60.0 \mathrm{~cm}$ flat-plate. A $4 \mathrm{~cm}$ thick polystyrene was used as the insulator.

The experiment was conducted under solar simulator with the used of 40 halogen lamps to distribute high radiation flux across the solar collector surface. The solar dryer was exposed under the light for $70 \mathrm{~min}$ where $50 \mathrm{~min}$ was for warming up the dryer before the test was done. This duration was chosen because according to our preexperiments, the temperature of the dryer will be constant after this period. The tests were conducted under two different parameters which were the radiation intensity and mass flow rate. The intensity values were selected based on the range of clear and blue-sky solar radiation, which are from 600 to $1000 \mathrm{~W} / \mathrm{m}^{2}$. Mass flow help to increase the moisture rate removal of humid air inside the drying chamber. The flow regime is considered to be laminar since the internal wind speed in the closed laboratory simulator system is not significant due to no external wind act inside the laboratory and the dryer. In this study, the intensities used were $625,708,860$, and $988 \mathrm{~W} / \mathrm{m}^{2}$, while the flow rates were $0.011,0.021,0.030$, and $0.041 \mathrm{~kg} / \mathrm{s}$. The flow rate depends on the air velocity of the fan, which was controlled by using a regulator, and was calculated by using equation (1). Every solar collector design presented in this study has been tested using the same flow rate to observe the temperature difference and the efficiency for each design. The radiation intensity values were collected by mapping the radiation value around the collector surface by using a pyranometer and monitored by a DL2e data logger.

\section{ENERGY ANALYSIS}

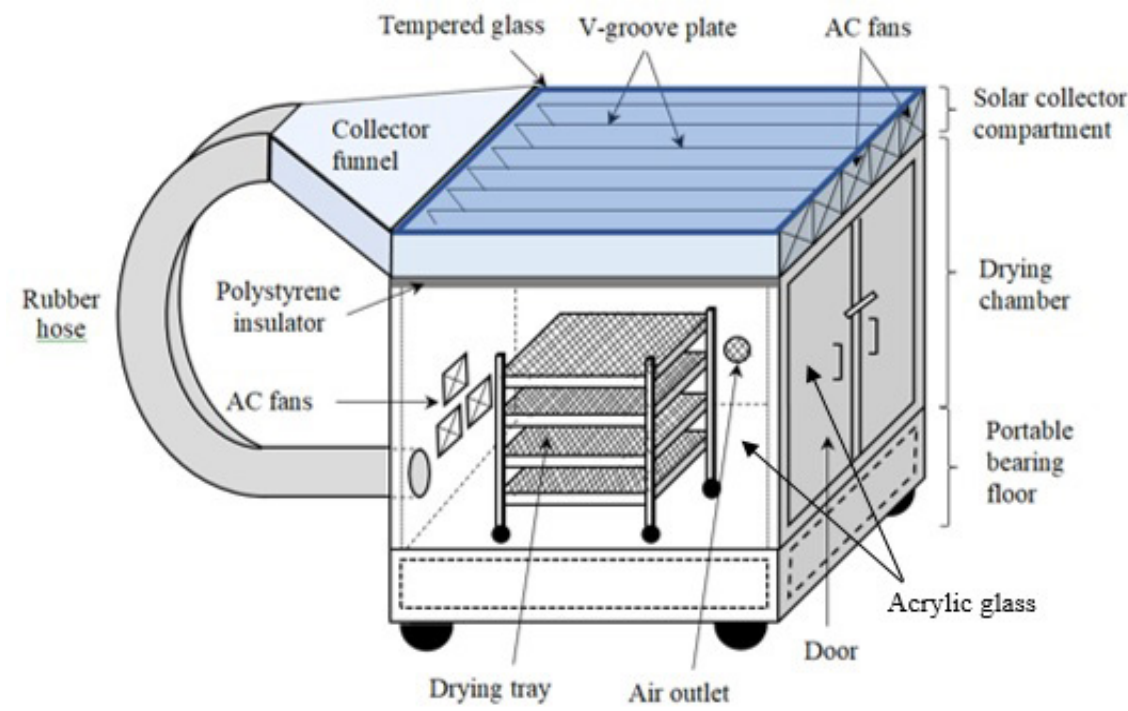

FIGURE 1. Schematic of the portable solar greenhouse dryer

(a)

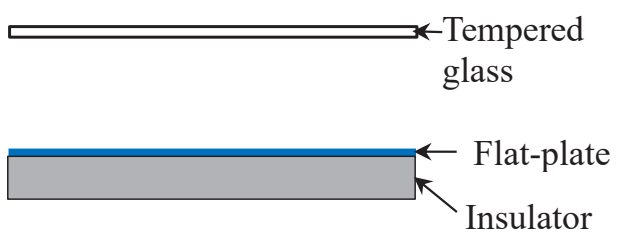

(c)

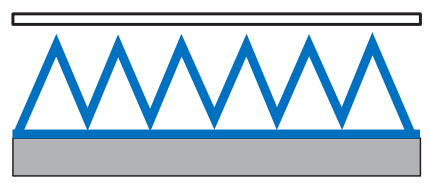

(b)

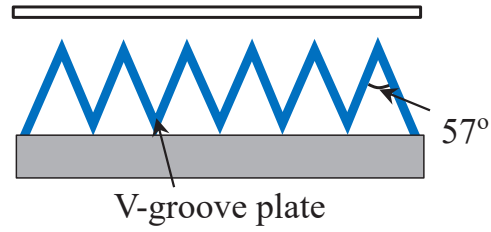

(d)

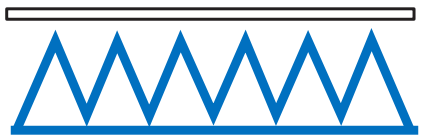

FIGURE 2. The solar collector arrangement of (a) flat-plate with insulator, (b) V-groove with insulator, (c) flat-plate and V-groove with insulator and (d) flat-plate and V-groove without insulator 
The mass flow rate, $\dot{\mathrm{m}}$ is calculated as:

$$
\dot{\mathrm{m}}=\rho A_{d} v
$$

where $\rho$ is density of air $\left(\mathrm{kg} / \mathrm{m}^{3}\right) ; A_{d}$ is the area of collector $\operatorname{duct}\left(\mathrm{m}^{2}\right)$; and $v$ is the air velocity $(\mathrm{m} / \mathrm{s})$. The equations of the thermal performance of a solar air heater are described as follows. The thermal heat energy, $Q_{u}$ of the circulated air across the solar collector can be calculated by using:

$$
\mathrm{Q}_{\mathrm{u}}=\dot{\mathrm{m}} \mathrm{C}_{\mathrm{p}}\left(\mathrm{T}_{\text {out }}-\mathrm{T}_{\mathrm{in}}\right)
$$

where $\dot{m}$ is the air mass flow rate $(\mathrm{kg} / \mathrm{s})$; and $\mathrm{C}_{\mathrm{p}}$ is specific heat capacity $(\mathrm{kJ} / \mathrm{kg} \mathrm{K})$ of air. $\mathrm{T}_{\text {out }}$ and $\mathrm{T}_{\text {in }}$ is the outlet and inlet collector temperature $\left({ }^{\circ} \mathrm{C}\right)$, respectively. The instantaneous thermal efficiency, $\eta$ of the solar collector can be described as the ratio of the amount of useful heat collected to the total amount of radiation striking the collector surface during any working time:

$$
\eta=\frac{Q_{u}}{A_{c} I_{t}}
$$

where $\mathrm{A}_{c}$ is the area of the collector $\left(\mathrm{m}^{2}\right)$; and $\mathrm{T}_{t}$ is the solar radiation incident on the solar collector $\left(\mathrm{W} / \mathrm{m}^{2}\right)$.

\section{RESULTS AND DISCUSSION}

For each experiment, the temperature of the collector outlet was collected after 50 minutes of exposure under the simulator to make sure the ambient temperature was under controlled. The change of outlet collector temperature with the mass flow rate at different solar radiation, for various solar collectors is shown in Figure 3. Overall, it can be seen that the outlet collector temperature decreases with the flow rate increment for all solar radiation intensity and all types of collector. Hence, the collector outlet temperature is the highest at the lowest mass flow rate of $0.01 \mathrm{~kg} / \mathrm{s}$. As the airflow rate in the collector increases, the hot air was being carried away faster by the flowing air and the heat energy of the incident solar radiation is less absorbed by the flat-plate collectors. Thus, less amount of heat is transferred to the collector outlet. As expected, the maximum solar radiation of $988 \mathrm{~W} / \mathrm{m}^{2}$ produces the highest outlet temperature regardless of the type of solar collector.

The highest collector outlet temperature for the flat-plate collector with insulator and the V-groove plate with insulator at $0.011 \mathrm{~kg} / \mathrm{s}$ mass flow rate and $988 \mathrm{~W} /$ $\mathrm{m}^{2}$ solar radiation intensities are $49.65{ }^{\circ} \mathrm{C}$ and 56.44 ${ }^{\circ} \mathrm{C}$, respectively. The V-groove plate could absorb much more amount of solar radiation than the flat-plate of equal absorptivity due to the larger surface area of the aluminium sheet that had been exposed to the radiation for the V-groove collector.
The outlet temperature of the solar collector was enhanced when the flat-plate and V-groove plate were combined due to the increasing surface area of the absorber, more heat is absorbed and transferred thus increasing the temperature. The combination of flat plate and V-groove with insulator achieved the outlet collector temperature of $58.44{ }^{\circ} \mathrm{C}$ which is higher than the combination of flat plate and V-groove without insulator which is $56.89^{\circ} \mathrm{C}$. Without the insulator, the thermal energy in the solar collector is transferred across rubber hose and to the solar drying chamber thus causing heat loss to the surrounding of the dryer.

The change of efficiency with mass flow rate and radiation intensity variation for various solar collectors is shown in Figure 4. At a constant solar radiation, as the flow rate increases, the collector efficiency also increases because of the heat losses to the surrounding. The highest mass flow rate gives out the maximum collector's efficiency at the lowest solar radiation intensity. The flatplate with insulator collector has the maximum collector's efficiency of $57.30 \%$ while $\mathrm{V}$-groove with insulator collector achieved much higher efficiency of $65.37 \%$ at the flow rate of $0.041 \mathrm{~kg} / \mathrm{s}$ and radiation intensity of 625 $\mathrm{W} / \mathrm{m}^{2}$. The temperature difference increases with solar radiation but with only slight changes. Therefore, for the same mass flow rate, the collector efficiency decreases as the solar radiation increases. The flat-plate collector gives out a low heat transfer coefficient, thus, resulted in lower thermal efficiency than V-groove plate.

At the same flow rate and radiation intensity, the combination of flat-plate and V-groove with insulator has the highest efficiency of $66.56 \%$, which is higher than the combination of flat-plate and V-groove without insulator which was $66.34 \%$. The combination of flatplate and V-groove plate with insulator has resulted in higher collector outlet temperature and efficiency with the increase of flow rate compared to without the usage of insulator. This is due to the heat that was transferred uniformly across the collector area towards the outlet of the collector. Higher outlet temperature and thermal efficiency will be achieved because of the insulator under the solar collector of the combination of flat-plate and $\mathrm{V}$-groove has reduced the heat loss. Meanwhile, the usage of solar collector of flat-plate and V-groove combination without insulator, has caused the heat energy in the collector area to not being transferred efficiently to the collector outlet because the heat from the collector has been supplied across the drying chamber due to no heat insulator as a barrier under the collector. Thus, its' efficiency has been reduced due to the heat exchange from collector to the drying chamber. From the graphs, as the mass flow rate increases, the collector's efficiency is increased at constant radiation for all types of solar collector arrangement. 
The drying chamber temperature is considered as the most important variable in crops drying process in solar drying. From the collector efficiency analysis, the highest efficiency achieved was at $0.01 \mathrm{~kg} / \mathrm{s}$ and $988 \mathrm{~W} / \mathrm{m}^{2}$. By using these two parameters result, the drying chamber temperature is plotted against various collector designs as shown in Figure 5. From the graph it is found that the combination of flat-plate and V-groove without insulator has higher drying chamber temperature than the other collectors. A part of the heat energy from the collector may have transferred down directly towards the drying chamber instead of flowing through the rubber hose because there was no insulation between the collector and the drying chamber. Thus, more heat was transferred and increased the drying chamber temperature.

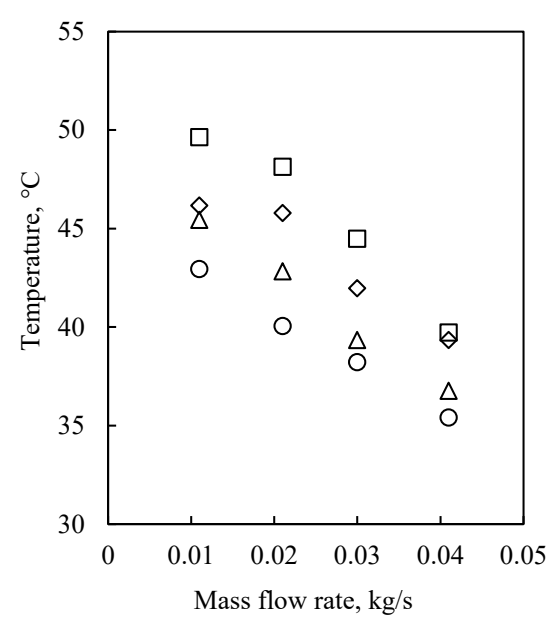

(a)

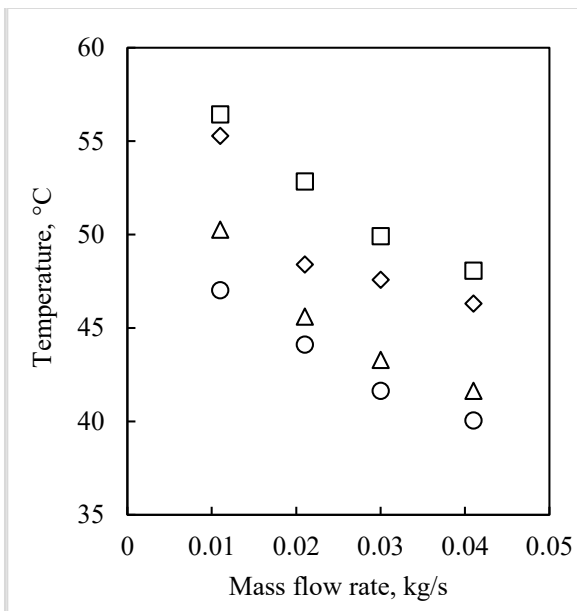

(b)

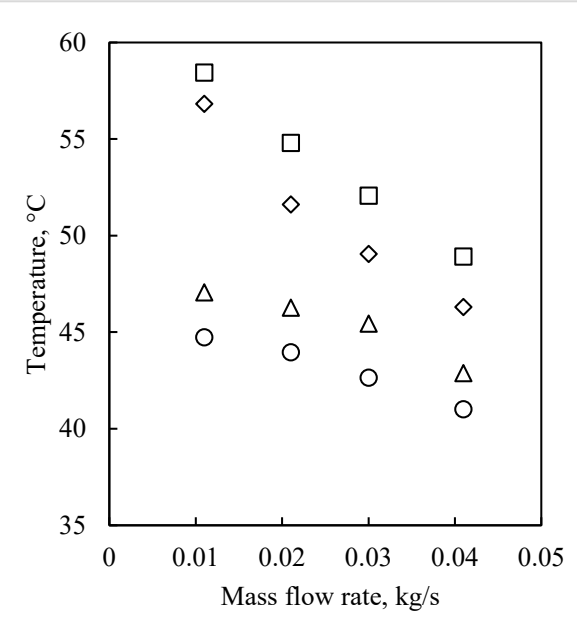

(c)

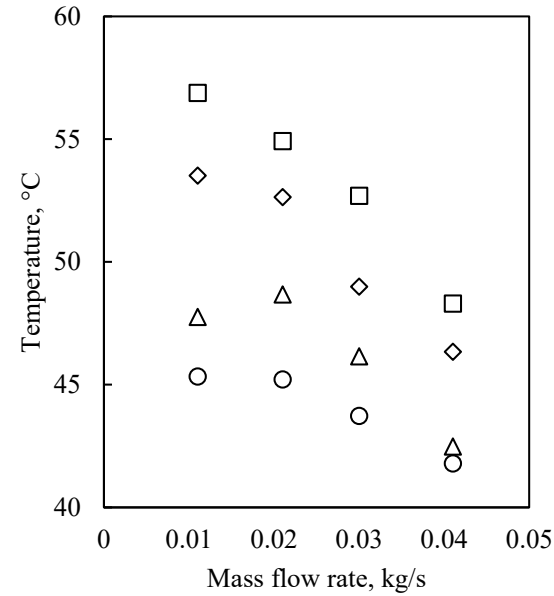

(d)

$0625 \mathrm{~W} / \mathrm{m}^{2} \quad \Delta 708 \mathrm{~W} / \mathrm{m}^{2} \quad \diamond 860 \mathrm{~W} / \mathrm{m}^{2} \quad \square 988 \mathrm{~W} / \mathrm{m}^{2}$

FIGURE 3. The collector outlet temperature with mass flow rate at different solar radiation for (a) flat-plate with insulator, (b) V-groove with insulator, (c) Flat-plate and V-groove with insulator and (d) flat-plate and V-groove without insulator 


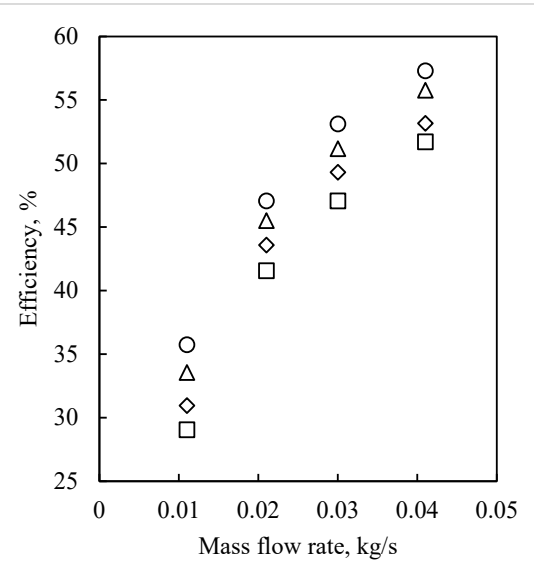

(a)

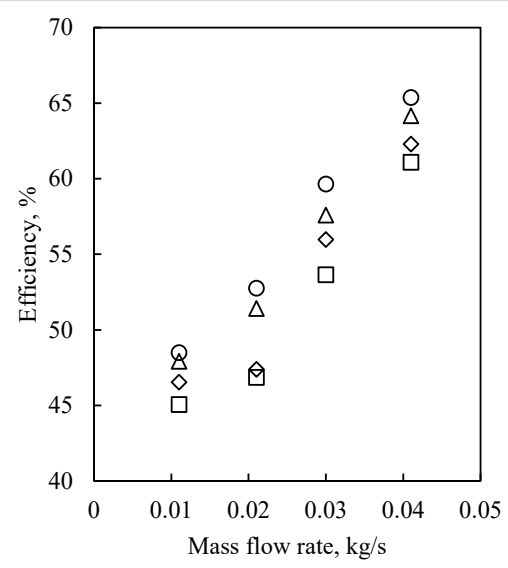

(b)

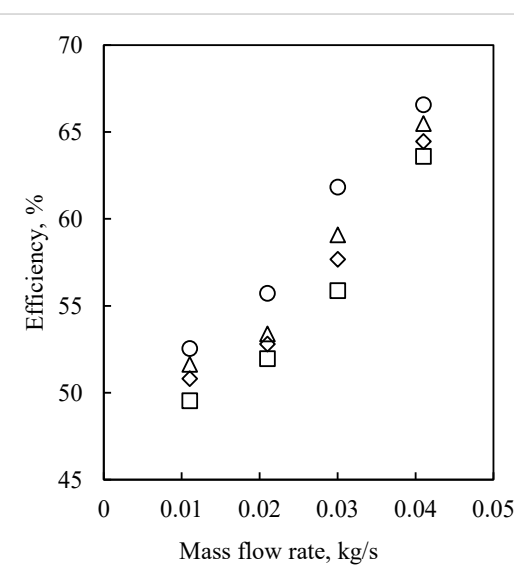

(c)

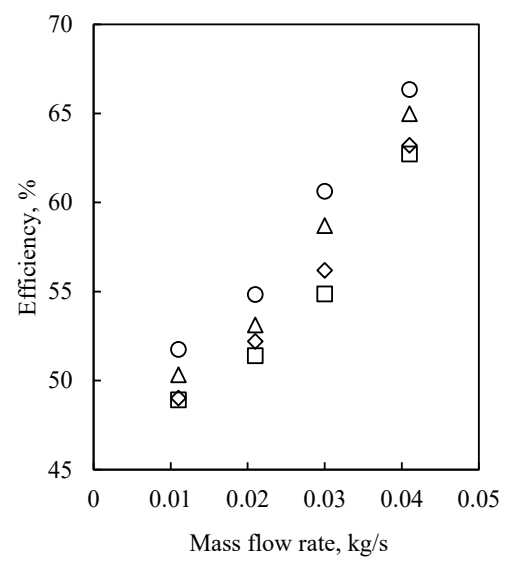

(d)

$0625 \mathrm{~W} / \mathrm{m}^{2} \quad \Delta 708 \mathrm{~W} / \mathrm{m}^{2} \quad \diamond 860 \mathrm{~W} / \mathrm{m}^{2} \quad \square 988 \mathrm{~W} / \mathrm{m}^{2}$

FIGURE 4. The efficiency change with mass flow rate at different solar radiation for (a) flat-plate with insulator, (b) V-groove with insulator, (c) Flat-plate and V-groove with insulator and (d) flatplate and V-groove without insulator

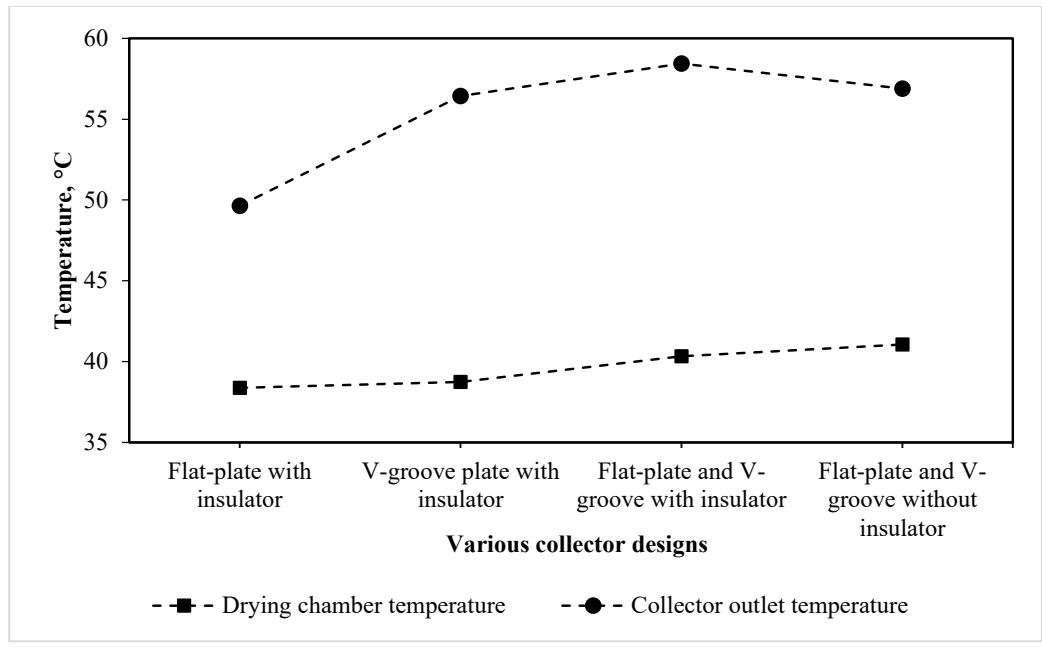

FIGURE 5. The drying chamber and collector outlet temperature against various collector designs 


\section{CONCLUSION}

As a conclusion, the solar collector achieved the highest thermal heat transfer with the use of a combination of flat-plate and V-groove collector with insulator. The use of flat-plate collector alone has resulted in lower thermal efficiency, while the use of V-groove only has achieved higher collector outlet temperature than the flat-plate due to the larger surface area of the V-groove collector. The combination of flat-plate and V-groove solar collectors with insulator has resulted in the highest outlet collector temperature and better thermal efficiency in comparison to the used of flat-plate, V-groove collector only and the combination of flat-plate and V-groove without insulator solar collector. Meanwhile, the best collector design for drying purpose is the combination of flat-plate and V-groove without insulator solar collector due to the highest drying chamber temperature achieved.

\section{ACKNOWLEDGEMENTS}

The authors would like to thank the Universiti Kebangsaan Malaysia for providing funds to this project under Geran Universiti Penyelidikan (GUP-2018-074) and the Department of Applied Physics, Faculty of Science and Technology, Universiti Kebangsaan Malaysia for the laboratory facilities.

\section{REFERENCES}

Chauhan, P.S. \& Kumar, A. 2016. Performance analysis of greenhouse dryer by using insulated north-wall under natural convection mode. Energy Reports 2: 107-116.

El-sebaii, A.A. \& Shalaby, S.M. 2012. Solar drying of agricultural products: A review. Renewable and Sustainable Energy Reviews 16(1): 37-43.

Essalhi, H., Tadili, R. \& Bargach, M.N. 2017. Conception of a solar air collector for an indirect solar dryer. Pear drying test. Energy Procedia 141: 29-33.

Evangelisti, L., Vollaro, R.D.L. \& Asdrubali, F. 2019. Latest advances on solar thermal collectors: A comprehensive review. Renewable and Sustainable Energy Reviews 114: 109318.

Fudholi, A. \& Sopian, K. 2019. A review of solar air flat plate collector for drying application. Renewable and Sustainable Energy Reviews 102: 333-345.

Fudholi, A., Othman, M.Y., Ruslan, M.H. \& Sopian, K. 2013. Drying of Malaysian Capsicum annuum L. (red chili) dried by open and solar drying. International Journal of Photoenergy 2013: Article ID. 167895.
Hassanien, R.H.E., Li, M. \& Lin, W.D. 2016. Advanced applications of solar energy in agricultural greenhouses. Renewable and Sustainable Energy Reviews 54: 989-1001.

Othman, M.Y.H., Fudholi, A., Sopian, K., Ruslan, M.H. \& Yahya, M. 2012. Analisis kinetik pengeringan rumpai laut Gracilaria changii menggunakan sistem pengering suria. Sains Malaysiana 41(2): 245-252.

Prakash, O. \& Kumar, A. 2014. Solar greenhouse drying: A review. Renewable and Sustainable Energy Reviews 29: 905-910.

Prakash, O., Kumar, A. \& Laguri, V. 2016. Performance of modified greenhouse dryer with thermal energy storage. Energy Reports 2: 155-162.

Shamekhi-Amiri, S., Gorji, T.B., Gorji-Bandpy, M. \& Jahanshahi, M. 2018. Drying behaviour of lemon balm leaves in an indirect double-pass packed bed forced convection solar dryer system. Case Studies in Thermal Engineering 12: 677-686.

Sopian, K. \& Othman, M.Y.H. 1992. Estimates of monthly average daily global solar radiation in Malaysia. Renewable Energy 2(3): 319-325.

Zulkifle, I., Alwaeli, A.H., Ruslan, M.H., Ibarahim, Z., Othman, M.Y.H. \& Sopian, K. 2018. Numerical investigation of V-groove air-collector performance with changing cover in Bangi, Malaysia. Case Studies in Thermal Engineering 12: 587-599.

Nurul Aiman Mhd Safri, Zalita Zainuddin* \& Idris Zulkifle

Department of Applied Physics

Faculty of Science and Technology

Universiti Kebangsaan Malaysia

43600 UKM Bangi, Selangor Darul Ehsan

Malaysia

Mohd Syahriman Mohd Azmi

Department of Physics

Faculty of Science and Mathematics

Universiti Pendidikan Sultan Idris

35900 Tanjong Malim, Perak Darul Ridzuan

Malaysia

Ahmad Fudholi \& Mohd Hafidz Ruslan

Solar Energy Research Institute

Universiti Kebangsaan Malaysia

43600 UKM Bangi, Selangor Darul Ehsan

Malaysia

*Corresponding author; email: zazai@ukm.edu.my

Received: 21 February 2020

Accepted: 24 April 2020 